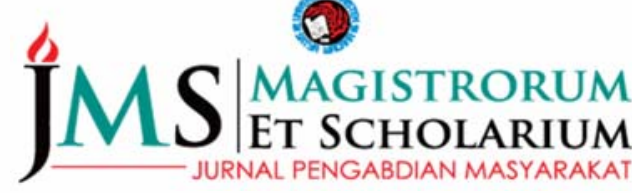 \\ P-ISSN: 2722-9270 ejournal.uksw.edu/jms
}

\section{Pendampingan Penguatan Tata Kelola Sistem Informasi Dinas Pertanian Kota Salatiga}

\author{
Aprina Nugrahesthy Sulistya Haspsari \\ Debora Herni Kurnianingtyas \\ Yosua Febrian Putra Aditya \\ Meike Indri Ferosa
}

Fakultas Ekonomika dan Bisnis, Universitas Kristen Satya Wacana; aprina@uksw.edu

A R T I C L E I N F O

Article history:

Received 12-07-2020

Revised 30-07-2020

Accepted 25-08-2020

Key words:

Audit Sistem Informasi, Sistem

$\mathrm{Pa}^{\prime}$ Tan, COBIT

\begin{abstract}
A B S T R A C T
Information Systems Audit is a mechanism that aims to ensure the internal control in the internal system of an organization has been running in accordance with the design set in an effort to achieve the goals set by evaluating and testing every activity carried out in the organization. In this article, the community service activities in the form of an information system audit on the Farming System in the Department of Agriculture of Salatiga City are explained. The audit was conducted using COBIT. Based on the audit result, it was found that the information system at the Department of Agriculture of Salatiga City, which is the Pa'Tani System, has been running smoothly and is well managed according to the desired goals and needs
\end{abstract}

\section{A B S T R A K}

Audit Sistem Informasi merupakan mekanisme yang bertujuan untuk memastikan pengendalian internal dalam sistem pada organisasi telah berjalan sesuai dengan desain yang ditetapkan dalam upaya mencapai tujuan yang telah ditetapkan dengan cara mengevaluasi dan menguji setiap aktivitas yang dilakukan dalam organisasi. Dalam artikel ini dipaparkan kegiatan pengabdian masyarakat berupa audit sistem informasi pada Sistem Pa'Tani di Dinas Pertanian Kota Salatiga. Audit dilakukan menggunakan COBIT. Berdasarkan hasil audit didapatkan bahwa sistem informasi pada Dinas Pertanian Kota Salatiga yaitu Sistem Pa'Tani sudah berjalan lancar dan dikelola dengan baik sesuai tujuan dan kebutuhan yang diinginkan. 
Pendampingan Penguatan Tata Kelola Sistem Informasi Dinas Pertanian Kota Salatiga (Aprina Nugrahesthy Sulistya Haspsari1, Debora Herni Kurnianingtyas, Yosua Febrian Putra Aditya, Meike Indri Ferosa)

\section{PENDAHULUAN}

Tugas tridharma perguruan tinggi meliputi pendidikan, penelitian serta pengabdian kepada masyarakat. Pendidikan yaitu proses pembelajaran untuk mengembangkan potensi, memiliki pengendalian diri, kepribadian, kecerdasan, akhlak mulia, serta keterampilan yang diperlukan dirinya, masyarakat, bangsa, dan negara. Penelitian merupakan kegiatan yang dilakukan secara sistematis untuk memperoleh informasi, data, pemahaman dan pengujian Pengabdian masyarakat merupakan kegiatan yang memanfaatkan ilmu pengetahuan dan teknologi untuk memajukan kesejahteraan masyarakat.

Pengabdian masyarakat dapat dilakukan dengan berbagai macam cara, salah satunya dapat dikaitkan dengan mata kuliah Praktik-Praktik Audit Sistem Informasi (PPASI). PPASI merupakan mekanisme yang bertujuan untuk memastikan pengendalian internal dalam sistem pada organisasi telah berjalan sesuai dengan desain yang ditetapkan dalam upaya mencapai tujuan yang telah ditetapkan dengan cara mengevaluasi dan menguji setiap aktivitas yang dilakukan dalam organisasi. Dalam artikel ini, objek PPASI diambil dari Sistem Pa'Tani di Dinas Pertanian Kota Salatiga.

Di era reformasi seperti saat ini dengan fenomena banyaknya tuntunan dari masyarakat terhadap good government governance mendorong pemerintah baik pusat maupun daerah untuk memberikan pertanggungjawaban yang lebih transparan, efisiensi dan lebih akurat. Namun, menurut data Indonesian Corruption Watch (ICW) kecurangan akuntansi sering ditemukan di organisasi perangkat daerah sejak tahun 2014.Kecurangan akuntansi terjadi karena adanya kesempatan, kurangnya pengawasan dan lemahnya pengendalian internal (Apriliana dan Budiarto, 2018). Salah satu kecurangan akuntansi yang sering terjadi adalah kecurangan sistem informasi pada organisasi perangkat daerah. Tersangka korupsi terbanyak adalah pejabat atau pegawai pemda/kementerian. Khusus semester II 2014, urutan terbanyak tersangka korupsi adalah Pelaksana Proyek (PP), Pejabat Pelaksana Teknis Kegiatan (PPTK), Kuasa Pengguna Anggaran (KPA), dan Pejabat Pembuat Komitmen (PPK).

COBIT yaitu Control Objectives for Information and Related Technology yang merupakan audit sistem informasi dan dasar pengendalian yang dibuat oleh Information Systems Audit and Control Association (ISACA), dan IT Governance Institute (ITGI) pada tahun 1992, meliputi: (1) Business information requirements, terdiri dari: information effectiveness (efektif), efficiency (efisien), (keyakinan), integrity (integritas), availability (tersedia), (pemenuhan), reliability (dipercaya), (2) Confidentiality compliance, (3) Information Technology Resource, terdiri dari : people, applications, technology, facilities, data, (4) High - Level IT Processes.

COBIT didasari oleh analisis dan harmonisasi dari standar teknologi informasi dan best practices yang ada, serta sesuai dengan prinsip governance yang diterima secara umum. COBIT berada pada level atas, yang dikendalikan oleh kebutuhan bisnis, yang mencakupi seluruh aktivitas teknologi informasi, dan mengutamakan pada apa yang seharusnya dicapai dari pada bagaimana untuk mencapai tata kelola, manajemen dan kontrol yang efektif. COBIT Framework bergerak sebagai integrator dari praktik IT governance dan juga yang dipertimbangkan kepada petinggi manajemen atau manager; manajemen teknologi informasi dan bisnis; para ahli governance, asuransi dan keamanan; dan juga para ahli auditor teknologi informasi 
dan kontrol. COBIT Framework dibentuk agar dapat berjalan berdampingan dengan standar dan best practices yang lainnya (Setiawan,2016).

Hakim et al. (2014) menyatakan bahwa hasil Perhitungan Domain Align, Plan, and Organize (APO) menunjukkan tingkat model kapabilitas skala penelitian penerapan framework COBIT 5 pada domain APO seperti ditunjukkan pada. Berdasarkan hasil tersebut, dapat disimpulkan bahwa hampir semua telah memenuhi skala target 3 (established pro-cess) dengan nilai indeks level rata-rata 4 dan nilai kesenjangan 1 hanya domain APO13 masih di bawah target. Hal ini menunjukkan bahwa TI KESDM sudah melakukan adanya suatu integrasi antara TI dengan tujuan organisasi KESDM, adanya suatu prioritas dalam investasi TI, adanya suatu keinginan dalam perencanaan pengembangan TI ke depan, serta adanya suatu tingkat koordinasi di lingkungan pengelola TI internal. Namun, pada sistem pengelolaan keamanan TI diperlukan suatu peningkatan karena hal ini penting dalam distribusi data dan kinerja para pengguna-pengguna TI di KESDM.

Hasil Perhitungan Domain Build, Acquire, and Implement (BAI) menunjukkan tingkat model kapabilitas skala penelitian penerapan framework COBIT 5 pada evaluasi tata kelola teknologi informasi di KESDM pada domain BAI berada pada skala target 3 (established process) dengan nilai rata-rata 3 dan nilai kesenjangan 0. Nilai tertinggi dari domain BAI2 dan BAI10 dengan nilai 5 dan tingkat kesenjangan -2 hal ini telah melewati target yang ditentukan, sedangkan domain BAI5 dan BAI6 dengan nilai 1,7 dengan nilai kesenjangan 1,3 yang masih di bawah target di tentukan dimana TI KESDM sudah melakukan pengelolaan kinerja TI sesuai dengan sasaran perencanaan, pemeliharaan infrastruktur TI, dan pengadaan barang TI sesuai dengan ketentuan standar pengadaan barang, namun masih adanya kelemahan pada sisi perubahan sistem baik dari segi software dan hardware disebabkan oleh tidak adanya pendokumentasian memadai.

Hasil Perhitungan Domain Deliver, Service and Support (DSS) menunjukkan tingkat model capability skala penelitian pe-nerapan framework COBIT 5 pada evaluasi tata kelola teknologi informasi di KESDM pada domain DSS berada pada skala target 3 (established process) dengan nilai rata-rata 4, dan nilai kesenjangan -1. Nilai tertinggi dicapai pada domain DSS1 dan DSS4 dengan nilai 5 dan nilai kesenjangan -2. Hal ini menandakan perlunya optimasi dalam hal implementasi dan pemeliharaan TI untuk menunjang kinerja organisasi. Namun, hal ini belum ditunjang dalam pengukuran tingkat kepuasan pelayanan umum. Penilaian tingkat kepuasan dalam pelayanan umum sangat penting untuk mengetahui sejauh mana pelayanan kinerja organisasi tercapai. Penilaian ini juga merupakan suatu penilaian yang dapat dijadikan rekomendasi untuk dapat meningkatkan pelayanan dalam bidang TI.

Hasil Perhitungan Domain Monitor, Evaluate, and Assess (MEA) menunjukkan tingkat model kapabilitas skala penelitian penerapan framework COBIT 5 pada evaluasi tata kelola teknologi informasi di KESDM pada domain MEA berada pada skala target 3 (established pro-cess) dengan nilai rata-rata 4 dan nilai kesenjangan 2 pada domain ini organisasi telah mengoptimalisasikan sistem pelaporan kinerja TI sesuai perencanaan dengan berpedoman pada kebijakan organisasi KESDM. Berdasarkan rekapitulasi rata-rata jawaban dari para responden, maka didapatkan nilai rata-rata tingkat kapabilitas saat ini sebesar 4 pada rentang 0 . Nilai kapabilitas tertinggi terdapat pada APO, DSS dan MEA yaitu sebesar 4, sedangkan nilai terendah terdapat pada EDM yaitu sebesar2. 
Pendampingan Penguatan Tata Kelola Sistem Informasi Dinas Pertanian Kota Salatiga (Aprina Nugrahesthy Sulistya Haspsari1, Debora Herni Kurnianingtyas, Yosua Febrian Putra Aditya, Meike Indri Ferosa)

Dalam pengabdian masyarakat ini, tujuan yang ingin dicapai adalah melakukan kegiatan audit sistem informasi pada Sistem Pa'Tani di Dinas Pertanian Kota Salatiga adalah untuk membantu menilai dan mengevaluasi terkait sistem pengendalian yang ada pada Sistem Pa'Tani di Dinas Pertanian Kota Salatiga apakah sudah diterapkan dengan benar atau tidak. Selanjutnya, dapat memberikan rekomendasikan bagi Dinas Pertanian Kota Salatiga terkait temuan-temuan yang perlu untuk ditindaklanjuti.

\section{METODE PELAKSANAAN}

Dalam pengabdian masyarakat ini, dilakukan audit sistem informasi pada Sistem Pa'Tani di Dinas Kota Salatiga. Untuk itu perlu dilakukan identifikasi bagaimana Sistem Pa'Tani beroperasi dari awal memasukkan data (input), proses, sampai kepada hasil (output) yang dikeluarkan. Tim pengabdian juga mengaudit pembagian tugas sumber daya manusia yang tersedia dari pranata komputer, kepala analis, hingga kepala dinas guna menilai apakah pengendalian terhadap resiko-resiko kemungkinan terjadi sudah cukup memadai. Dalam melakukan wawancara bersama narasumber, ditemukan beberapa resiko pada sistem yang belum dapat tertangani dengan baik misalkan ketika terjadi masalah pada perangkat keras yang digunakan untuk mendukung berjalannya sistem, pranata komputer yang bertugas untuk pemeliharaan dan perawatan akan menindak lanjutinya ketika adanya konfirmasi dari Infokom. Selain wawancara, tim pengabdian juga menemukan bukti audit dari dokumentasi kegiatan.

Dinas Pertanian Kota Salatiga sesuai dengan Peraturan Daerah Kota Salatiga Nomor 9 Tahun 2016 tentang Pembentukan dan Susunan Perangkat Daerah Kota Salatiga mempunyai tugas pokok melaksanakan kewenangan dibidang pertanian. Dinas Pertanian sebagaimana dimaksud dipimpin oleh kepala dinas yang berkedudukan di bawah dan bertanggung jawab kepada Walikota melalui Sekretaris Daerah. Dinas Pertanian dalam melaksanakan tugas memiliki beberapa fungsi yaitu: (1) merumuskan kebijakan teknis dibidang pertanian; (2) melaksanakan kebijakan pemerintahan dan pelayanan umum dibidang pertanian; (3) melaksanakan evaluasi dan pelaporan dibidang pertanian; (4) melaksanakan administrasi dinas pertanian; (5) melaksanakan fungsi lain yang diberikan oleh bupati terkait dengan tugas dan fungsinya. Dinas Pertanian Kota Salatiga memiliki visi "Melayani dengan sepenuh hati dan bahagia" dan memiliki lima misi yaitu: (1) melayani masyarakat dengan sepenuh hati jauh dari basa basi, (2) melayani dengan cepat dan murah, (3) memberikan pelayanan yang sama kepada semua kalangan, (4) memberikan pelayanan yang membahagiakan pelanggan, (5) meningkatkan kualitas pelayanan dengan memanfaatkan teknologi dan informasi. Dinas Pertanian Kota Salatiga memiliki moto yaitu melayani dengan sepenuh hati.

Struktur organisasi Dinas Pertanian Salatiga meliputi Kepala Dinas sebagai pimpinan tertinggi dalam dinas tersebut dibantu oleh Sekretariat. Dinas Pertanian memiliki empat bidang yaitu Bidang Tanaman Pangan, Bidang Perkebunan dan Hortikultura, Bidang Kesehatan Hewan dan Kesehatan Masyarakat Veteriner dan Bidang Budidaya, Kelembagaan dan Usaha Peternakan. Selain itu pada struktur organisasinya terdapat UPTD dan Kelompok Jabatan. Struktur organisasi Dinas Pertanian Kota Salatiga sebagai berikut: 


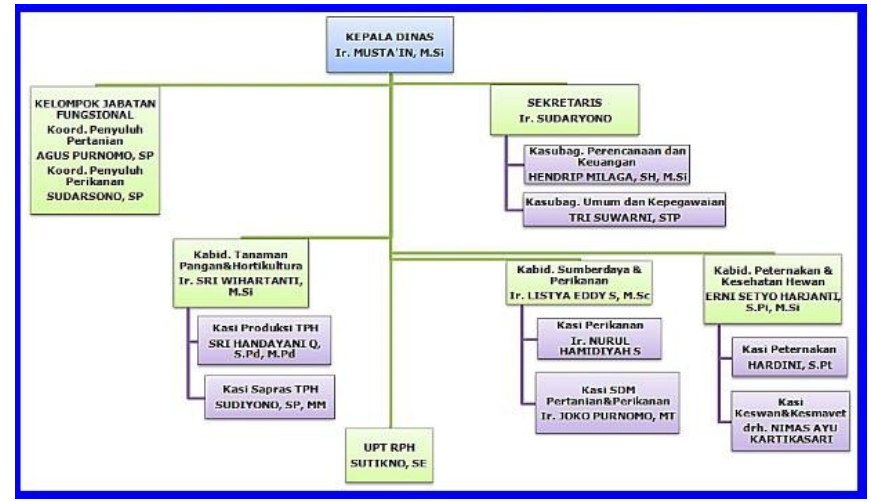

Gambar 1. Struktur organisasi dinas pertanian Salatiga

Sistem yang terdapat di Dinas Pertanian bernama Sistem Pa'Tani yang dioperasikan sejak tahun 2016 dan digunakan oleh para petani di Salatiga dengan tujuan mendukung berbagai strategi untuk keunggulan kompetitif, mendukung pengambilan keputusan dalam bisnis, dan mendukung proses dan operasi bisnis sehingga menjawab permasalahan ketahanan pangan melalui pemberdayaan petani dan pemanfaatan Teknologi Informasi. Dasar hukum pelaksanaan sistem yang ada di Dinas Pertanian Kota Salatiga yaitu Peraturan Walikota Salatiga, Nomor 11 Tahun 2016, Tentang Penyelenggaraan Pasar Komoditas Pertanian Melalui Sistem Elektronik dan Surat Keputusan Walikota Salatiga, Nomor 520- 05/257/2016, Tentang Tim Pengelola Pasar Online Produk Pertanian dan Perikanan.

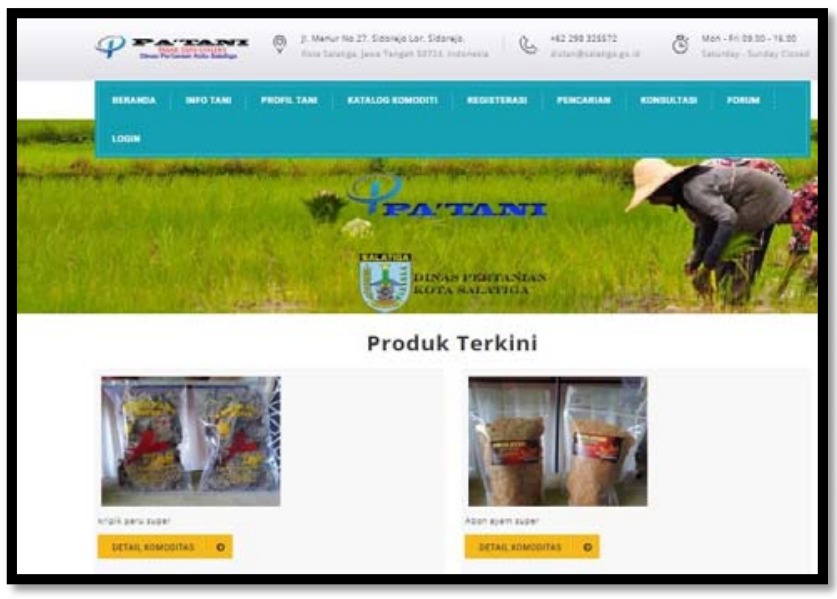

Gambar 2. Halaman we Pa'Tani

Pelaksanaan kegiatan dijadwalkan sebagai berikut:

Tabel 1. Jadwal pelaksanaan 
Pendampingan Penguatan Tata Kelola Sistem Informasi Dinas Pertanian Kota Salatiga (Aprina Nugrahesthy Sulistya Haspsari1, Debora Herni Kurnianingtyas, Yosua Febrian Putra Aditya, Meike Indri Ferosa)

\begin{tabular}{|c|c|c|c|}
\hline No. & Kegiatan & Person in Charge & Waktu \\
\hline 1. & Identifikasi Profil & Tim Auditor & 18 September 2019 \\
\hline 2. & Pemetaan ke dalam diagram RACI & Tim Auditor & 31 September 2019 \\
\hline 3. & Identifikasi Stakeholder needs & Tim Auditor & 31 September 2019 \\
\hline 4. & $\begin{array}{l}\text { Pemetaan ke dalam Enterprise } \\
\text { Goals }\end{array}$ & Tim Auditor & 13 Oktober 2019 \\
\hline 5. & Identifikasi IT-Related Goals & Tim Auditor & 20 September 2019 \\
\hline 6. & $\begin{array}{l}\text { Identifikasi Proses IT dalam setiap } \\
\text { sub domain }\end{array}$ & Tim Auditor & 4 November 2019 \\
\hline 7. & Penentuan Level Kapabilitas & Tim Auditor & 11 November 2019 \\
\hline 8. & Pembuatan Analisis Gap & Tim Auditor & 18 November 2019 \\
\hline
\end{tabular}

\section{HASIL DAN PEMBAHASAN}

Bagian ini memuat data (dalam bentuk ringkas), analisis data dan interpretasi terhadap hasil. Hasil kegiatan menjelaskan manfaat yang diterima oleh responden dan tindak lanjut mengenai kegiatan yang telah berlangsung. Serta menjelaskan manfaat dari siklus yang menjadi objek pelaksanaan.

Tabel 2. Diagram RACI

\begin{tabular}{lcccc}
\hline & Kepala Dinas & Kepala Analis & Pranata Komputer & Petani \\
\hline Responsible & $\mathrm{X}$ & $\mathrm{X}$ & $\mathrm{X}$ & \\
Accountable & & $\mathrm{X}$ & $\mathrm{X}$ & \\
Consultant & $\mathrm{X}$ & $\mathrm{X}$ & $\mathrm{X}$ \\
Informed & $\mathrm{X}$ & $\mathrm{X}$ & \\
\hline
\end{tabular}

Berdasarkan hasil observasi dan wawancara terkait peran dan tanggungjawab pihak- pihak yang berkepentingan dalam SI/TI di lapangan, dapat diketahui bahwa:

a. Kepala Dinas

Kepala Dinas memiliki tanggungjawab penuh terhadap Sistem Pa'Tani yang tersedia di Dinas Pertanian Kota Salatiga. Segala operasi yang ada pada sistem harus sesuai dengan otorisasi Kepala Dinas. Selain itu Kepala Dinas juga berperan dalam penyampaian hasil laporan dari Sistem Pa'Tani yang akan dipertanggungjawabkan kepada Walikota Salatiga serta dijadikan bahan untuk mensinkronkan antara barang-barang hasil tani yang dijual di sistem yang ada di Dinas Pertanian dan Dinas Perdagangan Kota Salatiga, serta mengkomunikasikan setiap kebijakan-kebijakan baru yang dikeluarkan oleh Walikota Salatiga terkait teknologi informasi yang harus diimplementasikan pada dinas.

b. Kepala Analis

Kepala Analis membawahi dua pranata komputer dan bertanggung jawab atas setiap operasi sistem yang dilakukan oleh pranata komputer seperti pemeliharaan dan perawatan peralatan baik hardware maupun software dalam mendukung aktivitas Sistem Pa'Tani. Kepala Analisi dapat bertanggungjawab kepada Kepala Dinas melalui laporan apakah sistem yang ada di Dinas Pertanian Kota Salatiga dapat berjalan dengan baik atau tidak. Dalam salah satu tools yang ada pada Sistem 
Pa'Tani juga memberikan layanan konsultasi kepada konsumen yang ditangani langsung oleh Kepala Analisis terkait hal-hal yang menyangkut hasil tani di Kota Salatiga. Kepala Analisis juga bertanggungjawab untuk memberikan pelatihan dan penyuluhan tentang teknologi dan informasi khususnya tentang Sistem Pa'Tani kepada para petani Kota Salatiga seperti bagaimana menggunakan sistem yang ada serta mengkomunikasikan setiap halangan yang dihadapi untuk menemukan solusinya bersama.

c. Pranata Komputer

Pranata Komputer dapat bertanggungjawab kepada Kepala Analisis melalui laporan kinerja sistem yang ada pada Dinas Pertanian Kota Salatiga. Seluruh aktivitas sistem pada Dinas Pertanian menjadi tugas pranata komputer mulai dari menginput data hingga menghasilkan laporan yang diperlukan oleh Kepala Analis maupun Kepala Dinas. Peran lain dari pranata komputer adalah sebagai salah satu konsultan dalam kolom konsultasi pada Sistem Pa'Tani atas setiap kendala yang dihadapi oleh konsumen dan petani.

d. Petani

Petani berperan dalam memberikan informasi terkait data yang dibutuhkan dalam sistem seperti jumlah ketersediaan barang dagangan hasil tani serta memperbaharui data-data yang diperlukan dalam sistem menyesuaikan dengan kebijakan Dinas Pertanian Kota Salatiga yang diturunkan dari kebijakan walikota dan kebutuhan pasar. 
Tabel 3. Identifikasi Stakeholder needs dan Pemetaan ke dalam EnterpriseGoals

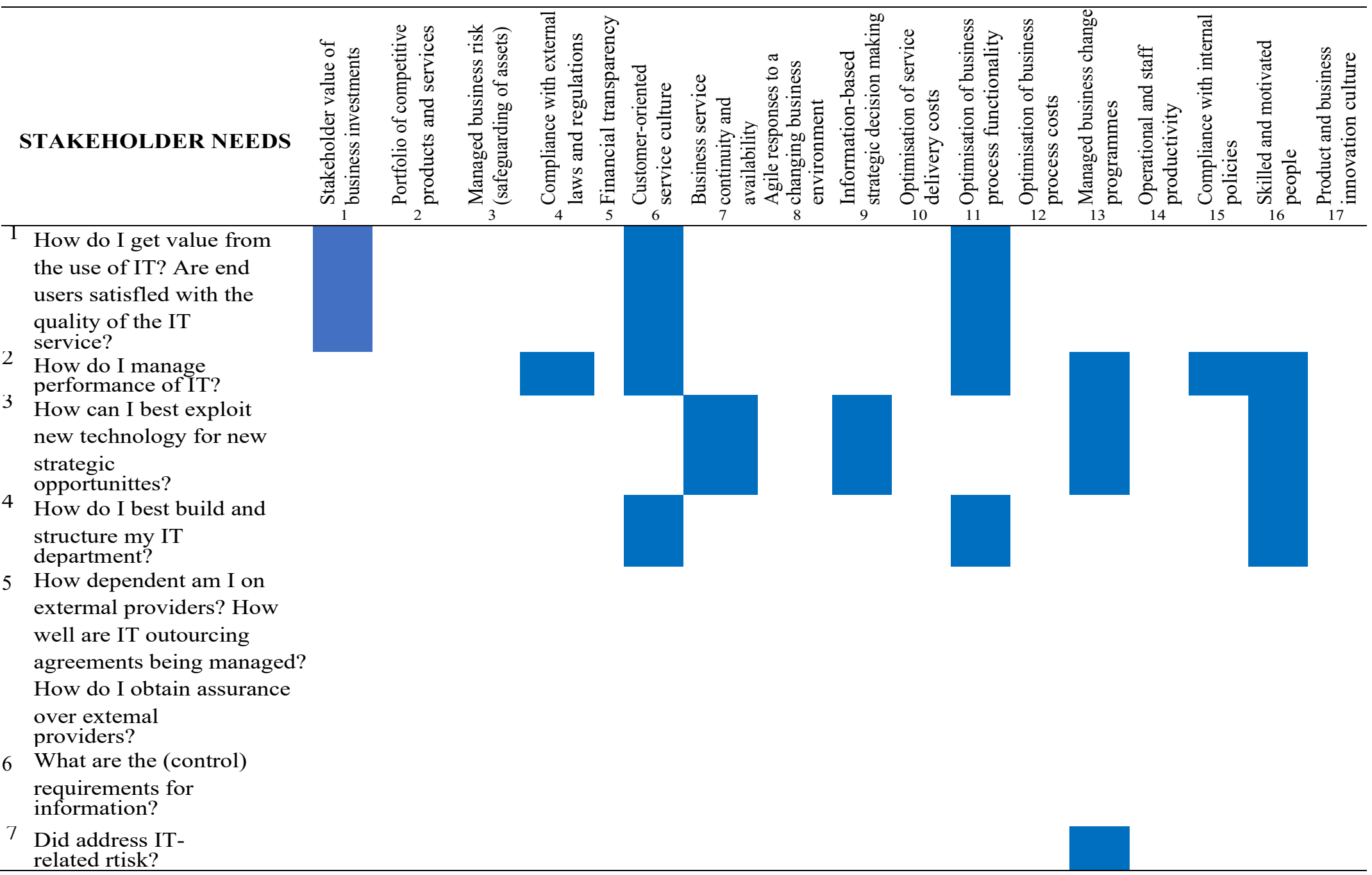


8 Am i running an eficient and resilent

IT operation?

9 How do I control the cost of IT? How do 1 use IT resources in the most eftective and efficient manner? What are the most effectve and

efficientsourcing options?

10 Do I have enough people for IT7 How do I develop and maintain ther skils, and how do I manage their performance?

11 How do get assurance over IT?

12 Is the information I am processing well secured?

13 How do I improve business agility through a more flexible IT environment?

14 Do IT projects fal to deltver what they promises-and it so, why? ls IT standing in the way of executing the business strategy?

15 How ortical is IT to sustaining the enterpriee? What do I do if IT is not

available?
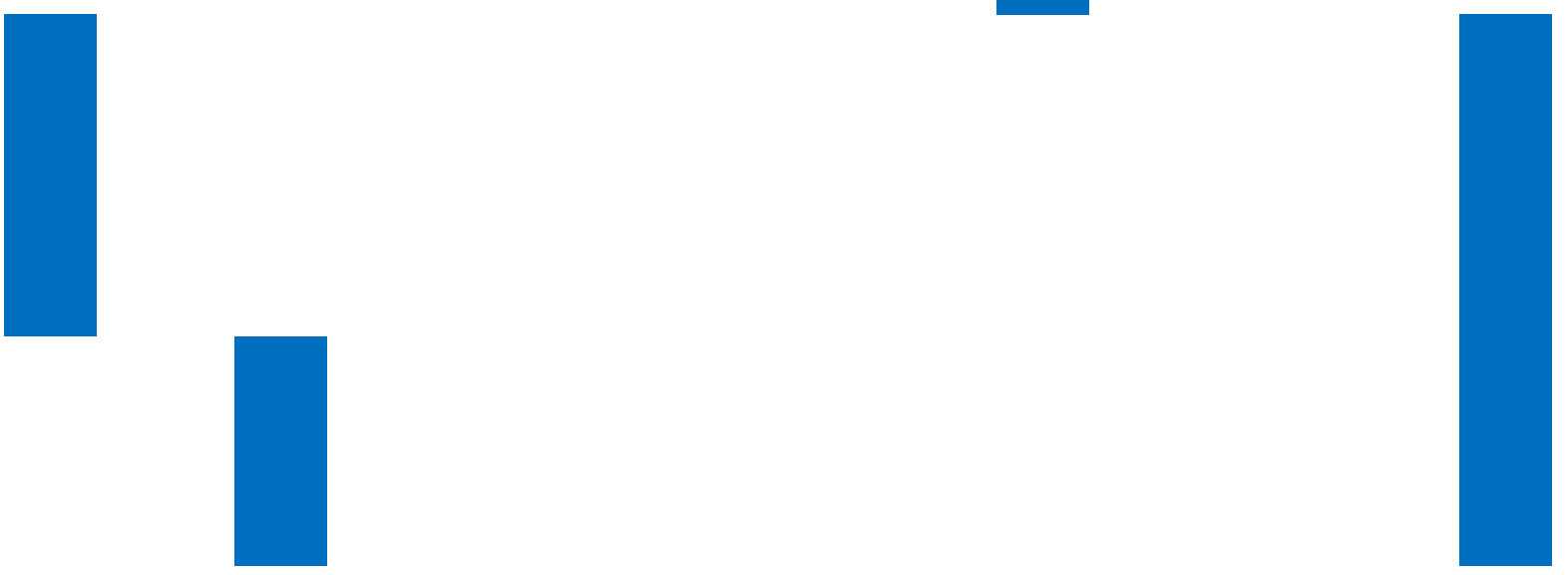
16 What critical business processes are dependent on IT, and what are the requirements of business processes?

17 What has been the average ovemun of the IT operational budgets? How often and how much do IT projects go over budget?

18 How much of the IT effort goes to fighting fires rather than to enabing business improvements?

19 Are sufficient IT resources and intrastructure available to meet required enterprise strategic objectives?

20 How long does it take to make major IT decisions?

21 Are the total IT effort and investments transparent?

22 Does IT support the enterpitse in complying with reguiations and service levels? compliant with all appllicable
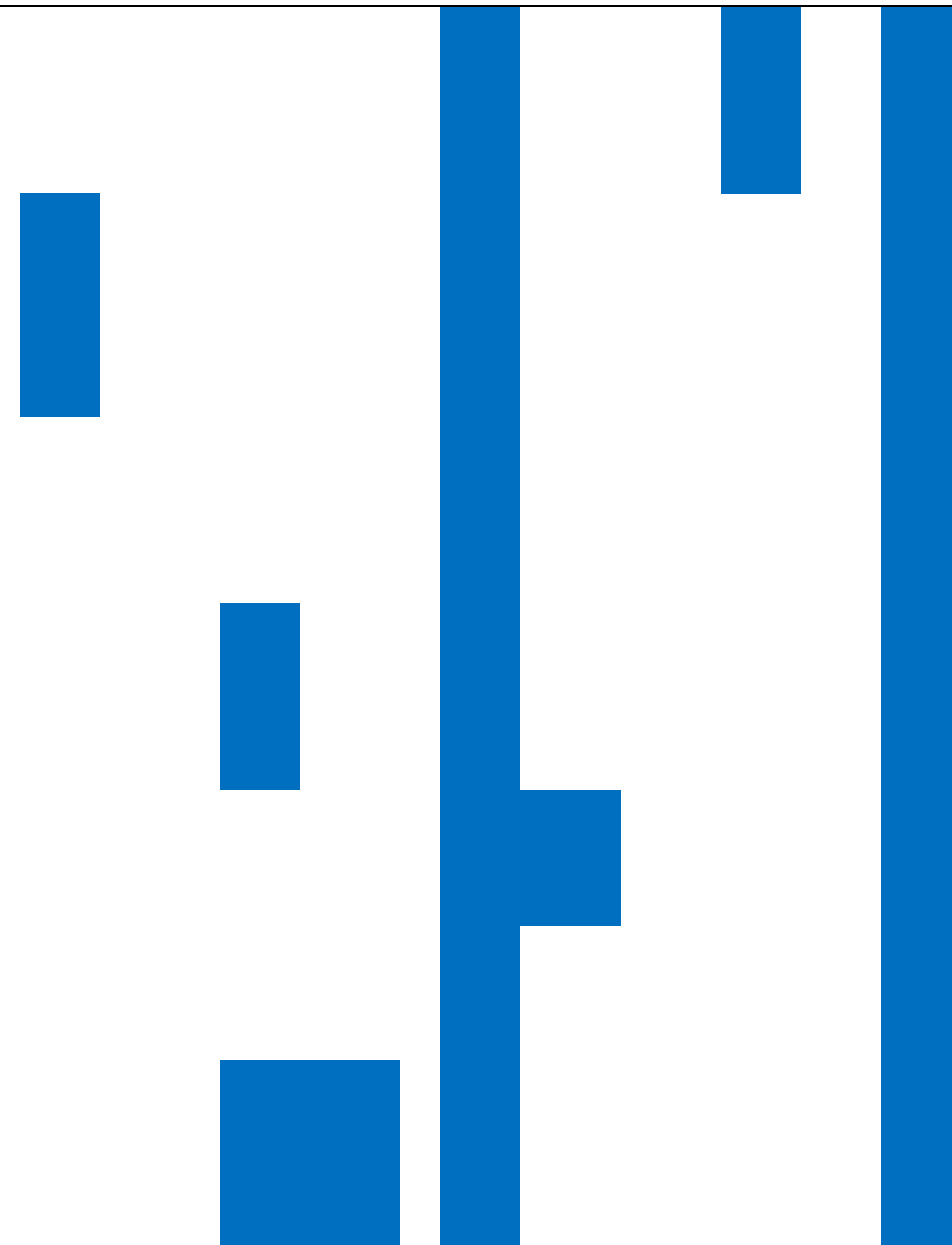

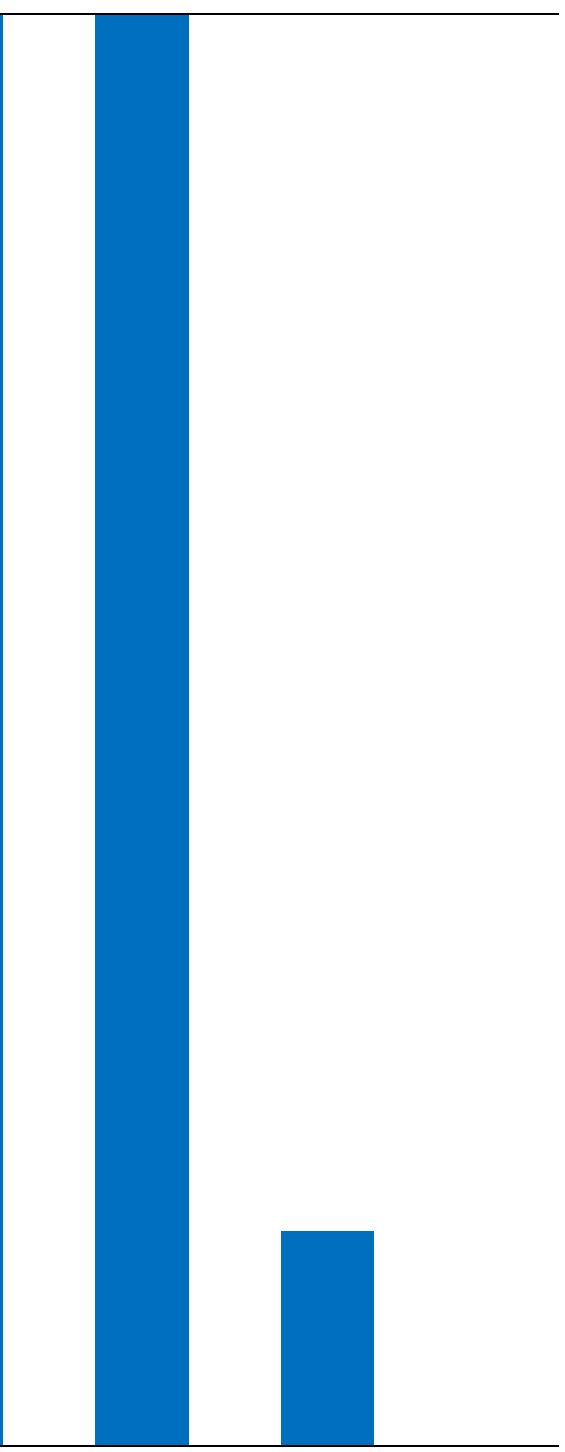


regulations?

23 How do I know my

business partner's

operations are secure

and reliable?

24 How do I know the

enterprise is compliant

with applicable nules and

regulations?

25 How do I know the

enterprise is maintaining

an etftective system of

intermal control?

26 Do business partners have

theinformation

chain

betweenthem under control 
Pendampingan Penguatan Tata Kelola Sistem Informasi Dinas Pertanian Kota Salatiga (Aprina Nugrahesthy Sulistya Haspsari1, Debora Herni

Kurnianingtyas, Yosua Febrian Putra Aditya, Meike Indri Ferosa)

Sistem Pa' Tani milik Dinas Pertanian kota Salatiga telah memberikan manfaat kepada stakeholder dalam hal pemotongan rantai distribusi hasil barang dagang tani. Hal ini menguntungkan beberapa pihak yang ada mulai dari sisi petani maupun sisi konsumen. Petani akan diuntungkan dikarenakan hasil tani tidak akan dijual melalui tengkulak lagi sehingga pendapatan mereka akan semakin meningkat. Dari sisi konsumen, mereka merasa diuntungkan secara finansial karena barang yang dicari tidak terlalu mahal karena langsung dari petani. Untuk mengoptimalkan sistem yang ada Dinas Pertanian melakukan pemeliharaan dan perawatan sistem dengan melibatkan sumber daya yang tersedia supaya sistem dapat digunakan secara optimal. Dinas Pertanian juga menganggarkan khusus biaya perawatan dan pemeliharaan yang digunakan apabila ada perangkat komputer yang digunakan untuk mendukung sistem terjadi kerusakan atau error yang dilakukan oleh pranata komputer.

Sistem Pa'Tani dapat membantu proses pemotongan rantai distribusi yang dilakukan oleh para petani yang ada di Kota Salatiga sehingga pendapatan yang diperoleh meningkat serta harga yang didapatkan oleh calon konsumen menjadi murah karena tidak memerlukan jasa dari tengkulak. Adanya Sistem Pa'Tani juga mempermudah konsumen untuk mendapatkan barang dagangan hasil tani yang diperlukan karena setiap tools yang tersedia di Sistem Pa'Tani dibuat berdasarkan kebutuhan lapangan meliputi harga, kuantitas hasil tani, berapa luas lahan sawah yang berada di Kota Salatiga serta berapa banyak kelompok tani yang sudah terdaftar di dalam Sistem Pa'Tani. Data-data yang diinput dalam Sistem Pa'Tani ini nantinya menghasilkan informasi yang digunakan oleh Dinas Pertanian dalam menentukan strategi operasi bisnis baru dalam Sistem Pa'Tani serta mensinkronkan informasi yang tersedia dengan Dinas Perdagangan supaya tidak ada yang tumpang tindih informasi.

Sistem Pa'Tani disesuaikan dengan persyaratan bisnis kebutuhan konsumen dan petani Kota Salatiga di pasar, dari sistem ini juga membantu Dinas Pertanian untuk mengetahui bagaimana pengelolaan hasil tani termasuk ketersediaan lahan, kuantitas yang dihasilkan setiap periode, serta harga pada barang dagang di Kota Salatiga. Dari setiap evaluasi terkait program Sistem Pa'Tani di Dinas Pertanian yang dilakukan setiap periode, dijadikan dasar oleh Kepala Dinas untuk mengambil keputusan terkait IT melakukan perbaikan secara terusmenerus. Dasar hukum pelaksanaan sistem yang ada di Dinas Pertanian Kota Salatiga yaitu Peraturan Walikota Salatiga, Nomor 11 Tahun 2016, Tentang Penyelenggaraan Pasar Komoditas Pertanian Melalui Sistem Elektronik dan Surat Keputusan Walikota Salatiga, Nomor 520-05/257/2016, Tentang Tim Pengelola Pasar Online Produk Pertanian dan Perikanan. Adanya kebijakan internal Dinas Pertanian terkait dengan pembuatan, pelaksanaan dan pengelolaan Sistem Pa'Tani diturunkan dari Peraturan Pemerintah Kota Salatiga.

Perbaikan dan pengembangan Sistem Pa'Tani dilakukan atas dasar analisis yang telah dilakukan oleh pranata komputer dan kepala analis terkait dengan evaluasi pelaksanaan dan pengelolaan sistem di lapangan berdasarkan kemampuan dan keterampilan yang mereka miliki melalui pendidikan formal dan informal. 
Tabel 4. Pemetaan Enterprise Goals terhadap IT Related Goals

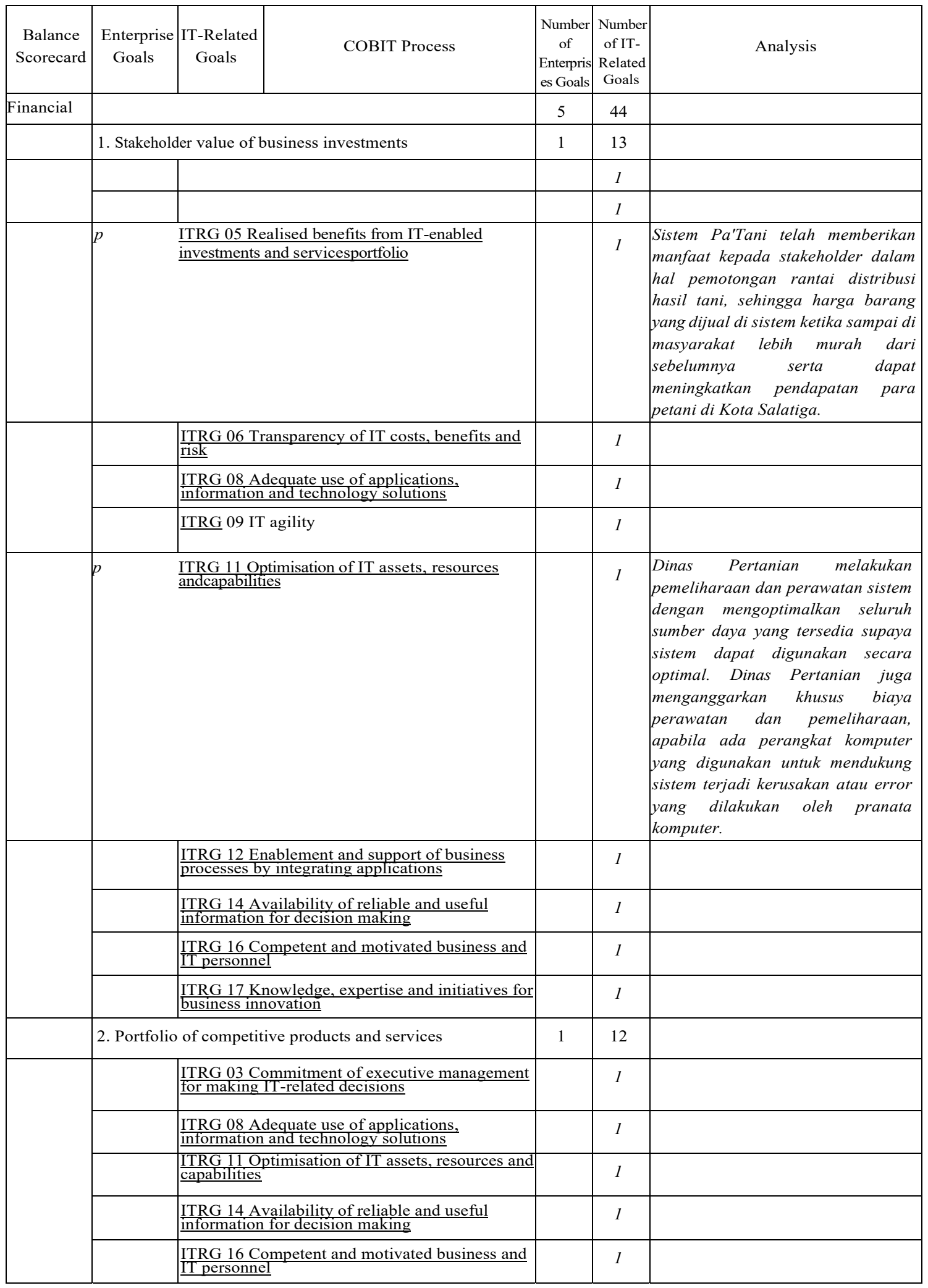




\section{Tabel 5. Pemetaan IT Related Goals terhadap COBIT process}

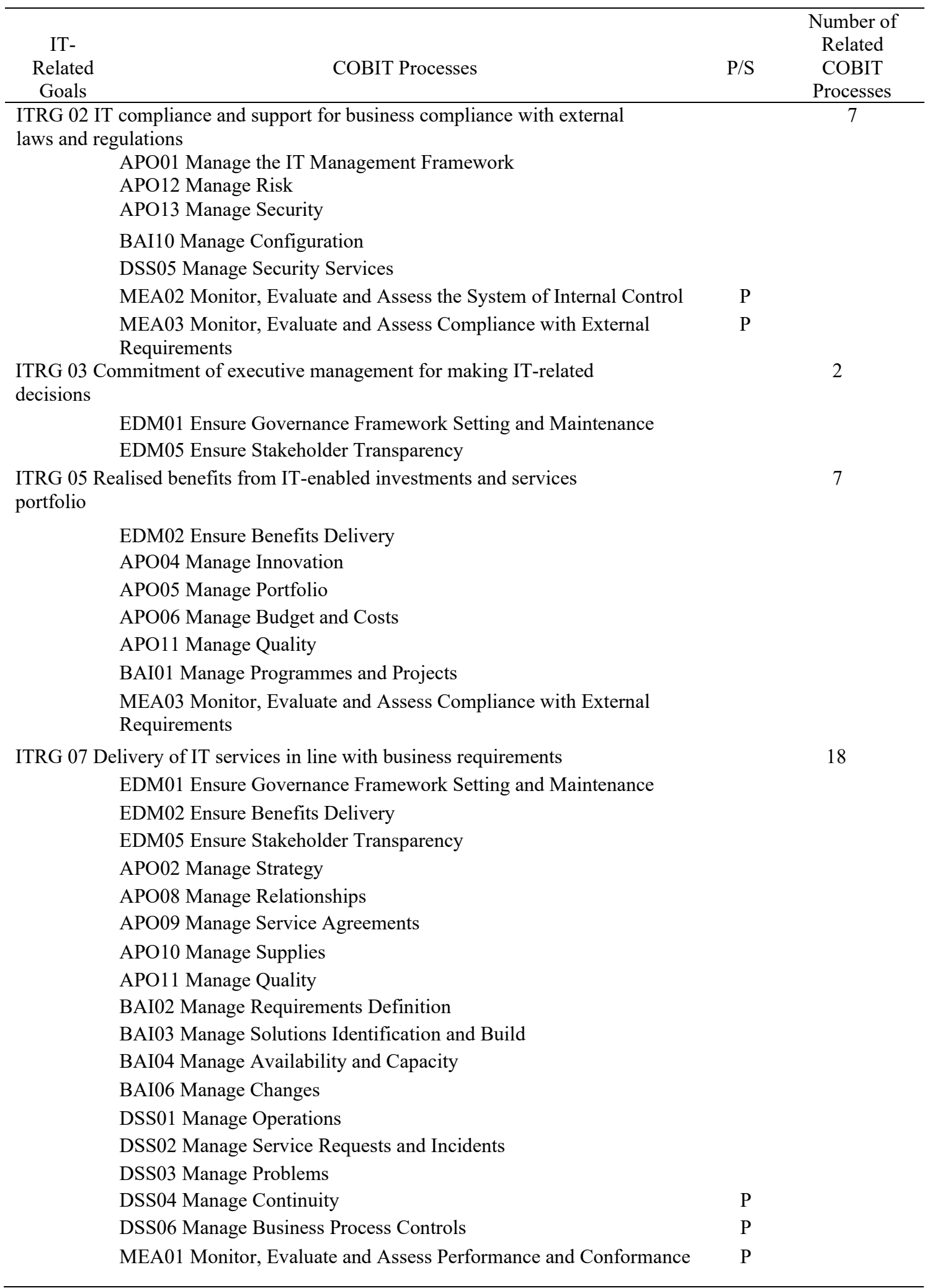


ITRG 11 Optimisation of IT assets, resources and capabilities

EDM04 Ensure Resource Optimisation

APO01 Manage the IT Management Framework

APO03 Manage Enterprise Architecture

APO04 Manage Innovation

APO07 Manage Human Resources

BAI04 Manage Availability and Capacity

BAI09 Manage Assets

BAI10 Manage Configuration

DSS01 Manage Operations

DSS03 Manage Problems

MEA01 Monitor, Evaluate and Assess Performance and Conformance

ITRG 14 Availability of reliable and useful information for decision making

APO09 Manage Service Agreements

APO13 Manage Security

BAI04 Manage Availability and Capacity

BAI08 Manage Knowledge

BAI10 Manage Configuration

DSS03 Manage Problems

DSS04 Manage Continuity

ITRG 15 IT compliance with internal policies

EDM03 Ensure Risk Optimisation

APO01 Manage the IT Management Framework

MEA01 Monitor, Evaluate and Assess Performance and Conformance

MEA02 Monitor, Evaluate and Assess the System of Internal Control

ITRG 16 Competent and motivated business and IT personnel

EDM04 Ensure Resource Optimisation

APO01 Manage the IT Management Framework

APO07 Manage Human Resources 
Tabel 6. Hasil Proses Penilaian

\begin{tabular}{|c|c|c|c|c|}
\hline $\begin{array}{l}\text { Cobit } 5 \\
\text { Process }\end{array}$ & Saat ini & Target & Optimal & Rekomendasi \\
\hline EDM01 & 1 & 2 & 5 & $\begin{array}{l}\text { Dinas Pertanian telah menerapkan kerangka tata pengaturan dan } \\
\text { pemeliharaan terhadap sistem informasi perusahaan berupa } \\
\text { standard tertulis serta membantu Dinas Pertanian dalam } \\
\text { pencapaian tujuan yaitu dengan memotong rantai distribusi hasil } \\
\text { tani di seluruh kota Salatiga sehingga dapat meningkatkan } \\
\text { pendapatan para petani. Semua data terkait hasil tani dapat diakses } \\
\text { melalui sistem ini. Sampai sekarang sistem ini terus mengalami } \\
\text { update dari Dinas Pertanian maupun Infokom. Namun dalam } \\
\text { pengaplikasiannya masih belum optimal, yaitu sistem ini masih } \\
\text { perlu melakukan perbaikan, karena para petani di Salatiga merasa } \\
\text { belum lancar dalam menggunakan sistem Pa'Tani sehingga update } \\
\text { yang dilakukan oleh petani sering terlambat. Kami menyarankan } \\
\text { agar Dinas Pertanian dapat memberi penyuluhan kepada petani } \\
\text { terkait sistem tersebut sehingga setiap hari petani dapat } \\
\text { mengupdate barang dagangan. Sebenarnya sistem Pa'Tani dapat } \\
\text { naik ke level selanjutnya karena akan ada rencana dari Dinas } \\
\text { Pertanian untuk memberikan penyuluhan kepada petani agar } \\
\text { informasi di sistem tersebut tidak terlambat dan sesuai dengan } \\
\text { standard tertulis. } \\
\text { Sistem Pa'Tani belum mampu memberikan informasi kepada }\end{array}$ \\
\hline EDM02 & 0 & 1 & 5 & $\begin{array}{l}\text { Sistem Pa'Tani belum mampu memberikan informasi kepada } \\
\text { masyarakat secara gesit pada respon kebutuhan masyarakat } \\
\text { dan keandalan informasi, dikarenakan dalam update data } \\
\text { barang dagangan tersedia pada Sistem Pa'Tani sering mengalami } \\
\text { keterlambatan karena petani belum terbiasa menggunakan sistem } \\
\text { tersebut. Jika Dinas Pertanian ingin naik level dalam pengelolaan } \\
\text { ini, kami menyarankan agar Dinas Pertanian mengontrol secara } \\
\text { rutin sistem di Pa'Tani dan Petani, sehingga setiap harinya barang } \\
\text { dagangan dapat diupdate dan memberikan informasi yang terbaru. } \\
\text { Sistem Pa'Tani dapat naik ke level selanjutnya karena dari analisis } \\
\text { komputer akan mengontrol sistem secara rutin mengingat } \\
\text { pentingnya informasi yang dibutuhkan. }\end{array}$ \\
\hline & & & & $\begin{array}{l}\text { Selama ini resiko-resiko yang terjadi masih dapat ditangani oleh } \\
\text { Dinas Pertanian melalui pranata komputer yang ada untuk } \\
\text { melaporkan ke Infokom maupun pihak ketiga terkait kendala yang } \\
\text { sedang dihadapi dan belum melebihi dampak resiko TI. Resiko- } \\
\text { resiko yang ada terkait dengan sistem baru akan didefinisikan dan } \\
\text { dikomunikasikan ketika sistem termasuk software dan hardware } \\
\text { mengalami error tidak ada penilaian resiko yang dilakukan oleh } \\
\text { Dinas Pertanian pada sistem Pa'Tani. Kami menyarankan agar }\end{array}$ \\
\hline EDM03 & 1 & 2 & 5 & $\begin{array}{l}\text { Dinas Pertanian membuat penilaian risiko sehingga risiko dapat } \\
\text { ditekan dan ditangani oleh Dinas Pertanian. sistem ini dapat } \\
\text { meningkat ke level selanjutnya karena akan merancangkan } \\
\text { penilaian risiko tertulis. }\end{array}$ \\
\hline & & & & $\begin{array}{l}\text { Sistem Pa'Tani dapat merespon dengan cepat apa yang menjadi } \\
\text { kebutuhan masyarakat karena sistemnya yang fleksibel dan mudah } \\
\text { untuk digunakan. Sistem Pa'Tani sudah menjalankan prinsip- } \\
\text { prinsip pengelolaan sumber daya secara konsisten dibuktikan } \\
\text { dengan adanya standar dan kebijakan khusus yang mengatur } \\
\text { tentang sumber daya terkait yang menangani sistem serta }\end{array}$ \\
\hline EDM04 & 1 & 1 & 5 & $\begin{array}{l}\text { melakukan sosialisasi kebijakan tersebut kepada para petani yang } \\
\text { menggunakan sistem. Dinas Pertanian belum memenuhi standar } \\
\text { yang tepat dalam sumber daya terkhusus pada SDM dikarenakan }\end{array}$ \\
\hline
\end{tabular}


banyak sistem yang

digunakan oleh Dinas Pertanian namun SDM yang tersedia terbatas sehingga pranata komputer dan kepala analis harus membackup seluruh sistem yang ada di Dinas Pertanian Kami menyarankan agar sumber daya Pranata Komputer bisa ditambah lagi agar sistem yang ada di Dinas Pertanian dapat berjalan dengan baik dan jika ada error di dalam sistem bisa tertangani dengan efektif dan efisien. sistem Pa'Tani akan tetap mempertahankan di dalam level ini karena Dinas Pertanian harus mengoptimalkan sumber daya manusia yang mengelola sistem ini, karena belum memungkinkan untuk menambah jumlah sumber daya manusia.

Sistem Pa'Tani terus mengalami peningkatan efisiensi biaya TI dan juga kontribusinya dalam profitabilitas dibuktikan dengan adanya pembaharuan sistem secara berkala dalam rangka pemenuhan kebutuhan pengguna maupun masyarakat agar dapat menggunakannya secara mudah dan tepat sasaran. Sistem Pa'Tani menyediakan kolom khusus untuk para pemangku kepentingan apabila mendapatkan keluhan terhadap sistem serta dapat melakukan konsultasi apabila ada kendala terkait sistem maupun hasil tani di Kota Salatiga. Pelaporan output dari Sistem Pa'Tani terkadang mengalami keterlambatan dikarenakan update data yang dilakukan oleh para petani juga terlambat sehingga

$\begin{array}{llll}\text { EDM05 } & 1 & 2 & 5\end{array}$

APO01 1125

APO02 1125

$\begin{array}{lllll}\text { APO03 } & 0 & 1 & 5 & \text { mengandalkan Dinas Kominfo saja saat sistem mengalami eror, }\end{array}$

kelengkapan data pun sering kurang, kami menyarankan agar Dinas Pertanian dapat memantau sistem di Pa'Tani secara rutin dan memberikan penyuluhan kepada petani agar dapat mengupdate dengan tepat waktu. Sistem Pa'Tani dapat meningkat ke level selanjutnya karena dapat terus mengalami peningkatan efisiensi dan pembaharuan sistem.

Sistem Pa' Tani belum maksimal dalam memberikan informasi kepada masyarakat serta para petani masih terkendala dengan teknologi sehingga terdapat kendalaketerlambatan dalam update informasi yang ada dalam sistem. Sistem Pa' Tani memiliki pedoman berupa

peraturan eksternal dan peraturan internal, peraturan eksternal merupakan peraturan dari Pemerintah Kota Salatiga, sedangkan peraturan internal merupakan peraturan dari Dinas Pertanian Salatiga. Kebijakan internal terkait IT sudah dikomunikasikan dengan karyawan khususnya prakom, setiap prakom juga harus memenuhi persyaratan tertentu. kami menyarankan agar Dinas Pertanian dapat memberikan penyuluhan lebih lanjut terkait sistem ini kepada masyarakat dan petani agar lebih dapat dimaksimalkan penggunaanya.

Sistem Pa' Tani di kelola oleh prakom yang akan di koordinasikan lebih lanjut ke diskominfo. Untuk menjadi prakom harus memenuhi syarat tertentu salah satunya adalah paham dengan teknologi informasi. saat terdapat kendala dalam sistem yang tidak bisa diselesaikan oleh Prakom Dinas Pertanian maka kendala tersebut akan diserahkan oleh Dinas Kominfo yang memiliki wewenang lebih terkait dengan segala sistem yang ada. Kami menyarankan agar ada prakom yang memiliki tugas khusus merawat dan bertanggung jawab penuh atas sistem tersebut.

Tidak ada strategi khusus yang dibuat oleh Dinas Pertanian terkait Sistem $\mathrm{Pa}^{\prime}$ Tani dalam hal kelanjutan dan perkembangan sistem tersebut, hal ini dibuktikan dengan sistem yang eror dan sampai sekarang perbaikan masih belum dilakukan secara maksimal. Kami menyarankan agar Dinas Pertanian tidak hanya mengandalkan Dinas Kominfo saja saat sistem mengalami eror, 
sebaiknya Dinas Pertanian juga memiliki strategi khusus untuk meminimalisir terjadinya eror. $\begin{array}{llll}\text { APO04 } & 0 & 1 & 5\end{array}$

APO06 $\quad 1 \quad 22 \quad 5$

APO07

2 5

(1)

(1)

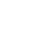

Sumber daya yang terdapat dalam Dinas Pertanian dinilai belum digunakan secara optimal dikarenakan setiap satu pranata komputer harus menangani beberapa sistem yang berada di beberapa bidang pada Dinas Pertanian dan tidak

bisa berfokus pada resiko-resiko yang mungkin dihadapi oleh Sistem Pa'Tani. Tidak ada tugas dan fungsi khusus bagi prakom untuk fokus pada sistem tersebut. Kami menyarankan agar ada prakom yang memiliki tugas khusus merawat dan bertanggung jawab penuh atas sistem tersebut agar fokus dari prakom sendiri tidak terbagi-bagi.

Sistem Pa'Tani mencapai tujuannya mempertahankan atau memperluas strategi bisnis dengan cara mengupdate sistem secara berkala, update dilakukan dua pihak dari Dinas Pertanian dan dari para petani. Tidak ada anggaran khusus yang dialokasikan Dinas Pertanian untuk sistem Pa' Tani, Dinas Pertanian tidak melakukan perbandingan antara biaya dengan aktualnya karena yang melakukan anggaran sistem adalah infokom. Kami menyarankan agar Dinas Pertanian dan Dinas Kominfo lebih berkoordinasi terkait dengan anggaran kebutuhan yang nantinya akan dialokasikan untuk sistem Pa' Tani.

Dinas Pertanian memiliki peran prakom dan kepala analis untuk bertanggung jawab memelihara hal-hal yang diperlukan dalam sistem Pa'Tani untuk mencapai tujuan organisasi agar sistem Pa'Tani masih dapat bertahan. Untuk menjadi prakom ada beberapa syarat yang harus dipenuhi meliputi memiliki keterampilan, kompetensi, dan kemampuan yang memadai harus berasal dari lulusan TI dan sudah mengikuti pelatihan yang diperlukan untuk mencapai tujuan organisasi. Kami menyarankan agar setiap prakom yang ada ditempatkan sesuai dengan keahliannya, agar setiap prakom dapat mengupgrade dan mengembangkan keahliannya lagi.

Sistem $\mathrm{Pa}$ ' Tani disesuaikan dengan standar kebijakan yang dikeluarkan oleh pemerintah kota dalam menunjang penggunaan sistem dengan hal ini maka sistem tersebut dapat berjalan sejalan dengan peraturan yang ada Strategi, rencana,

dan persyaratan di dalam sistem Pa'Tani dipahami dengan baik, didokumentasikan dan disetujui oleh Kepala Dinas Pertanian. Terdapat hubungan yang baik antara Dinas Pertanian dan TI (Dinas Kominfo), sehingga jika sistem tidak berjalan dengan baik akan dikoordinasikan lebih lanjut ke Dinas Kominfo untuk dilakukan perbaikan. Masyarakat juga merasakan manfaatnya yaitu lebih mudah untuk mendapatkan barang yang lebih murah dan tidak perlu bertemu langsung dengan petani.

Dinas Pertanian memastikan kepuasan yang diterima masyarakat dengan adanya layanan konsultasi dan aduan yang terdapat dalam Sistem Pa'Tani dan tingkat layanan serta mengintegrasikan penggunaan aplikasi tersebut. Layanan tersebut digunakan Dinas Pertanian untuk mengembangkan sistem $\mathrm{Pa}$ ' Tani. Layanan sistem Pa'Tani mencerminkan kebutuhan perusahaan dan kemampuan TI sehingga pranata komputer dapat menangani sistem tersebut serta mengoperasikannya. Kami menyarankan agar Dinas Pertanian 
memberikan penyuluhan kembali terkait sistem dan layanan yang terdapat dalam sistem tersebut.

$\begin{array}{llll}\text { APO10 } & 1 & 2 & 5 \\ \text { APO11 } & 0 & 1 & 5\end{array}$

$\begin{array}{llll}\text { APO12 } & 1 & 1 & 5\end{array}$

$\begin{array}{llll}\text { APO13 } & 1 & 1 & 5\end{array}$

$\begin{array}{llll}\text { BAI01 } & 1 & 1 & 5\end{array}$
Sistem Pa'Tani dapat meningkatkan efektivitas, efisiensi biaya, dan kontribusi terhadap profitabilitas bisnis. Hal ini dibuktikan bahwa para pengguna sistem Pa'Tani dapat dimudahkan dalam mencari kebutuhan pangan tanpa harus bertemu langsung dengan petani begitu juga harga yang ditawarkan lebih murah daripada harga di pasar. Kami menyarankan agar Dinas Pertanian memberikan penyuluhan kembali terkait sistem dan manfaatmanfaat yang terdapat dalam sistem tersebut.

Dinas Pertanian dirasa belum maksimal dalam hal perbaikan sistem ketika ada cacat, hal ini dibuktikan bahwa sistem masih terdapat eror dan belum diperbaiki secara optimal sehingga mengganggu jalannya proses bisnis yang ada. Kami

menyarankan agar Dinas Pertanian melakukan pengecekan dan perawatan secara berkala terkait dengan kinerja sistem tersebut, agar berbagai permasalahan dapat diminimalisir.

Sistem Pa' Tani di Dinas Pertanian merupakan sistem baru yang bertujuan untuk memotong rantai distribusi barang hasil tani sampai ke konsumen, sejak pemasangan sampai sekarang masih terdapat kendala dalam hal instalasi maka dari itu Dinas Pertanian masih berusaha untuk melakukan perbaikan dan pengembangan sistem agar eror bisa diminimalisir. Kami menyarankan agar Dinas Pertanian memanfaatkan secara maksimal sumber daya yang ada di Dinas Pertanian sendiri, yaitu tugas prakom dapat difokuskan untuk penanganan dan perawatan sistem Pa' Tani.

Setiap user yang ada dalam Sistem Pa' Tani diperlengkapi dengan username dan password untuk menunjang keamanan dari datadata dan menghindari penyalahgunaan data-data pribadi, Dinas Pertanian menganggap username dan password sudah dirasa cukup dalam hal pengamanan yang terdapat dalam sistem tersebut. Tidak ada spesifikasi khusus untuk username dan password yang ada. Kami menyarankan agar Dinas Pertanian menyiapkan spesifikasi khusus untuk username dan password yang ada agar informasi yang ada lebih terjamin.

Sistem Pa'Tani sudah baik dalam menyediakan layanan untuk pihak ketiga yang dapat memuaskan sambil tetap transparan tentang manfaat, biaya, dan risiko. Manfaat yang diharapkan dari program tersebut dapat tercapai dan diterima yaitu dapat memotong rantai distribusi. Tetapi adanya kekurangan sumber daya untuk melakukan kegiatan sistem tersebut sehingga jika sistem tersebut error akan membutuhkan waktu yang cukup lama untuk menangani hal tersebut. kami menyarankan agar sumber daya manusia ditambah agar penanganan terhadap eror dapat segera diatasi

dan melakukan pemeliharaan secara rutin. sistem Pa'Tani akan tetap mempertahankan level ini karena adanya kesulitan untuk bisa menambah jumlah sumber daya manusia yang ditugaskan untuk menangani error tersebut. 
Sistem Pa'Tani telah mengoptimalkan kinerja, sumber daya, dan kemampuan TI dalam menanggapi kebutuhan bisnis dan telah mencerminkan kebutuhan dan harapan perusahaan.

tetapi risiko yang terdapat dalam sistem Pa'Tani belum dapat teratasi karena sumber daya manusia untuk menangani error tersebut terbatas dan harus menginformasikan ke infokom jika error tidak bisa ditangani sementara oleh pranata komputer sehingga memerlukan waktu yang cukup lama untuk menangani error tersebut. kami menyarankan agar prana komputer benarbenar memahami sistem Pa'Tani dan mempunyai strategi khusus

$\begin{array}{llll}\text { BAI02 } & 1 & 2 & 5\end{array}$

BAI03 $\quad 0 \quad 1 \quad 5$

BAI04 1125

BAI06 $11 \quad 1 \quad 5$

BAI08 1125 untuk menangani error. sistem

Pa'Tani dapat naik ke level selanjutnya karena sumber daya manusia telah memenuhi persyaratan seperti pendidikan formal dan informal sehingga pengetahuan mengenai teknologi dapat bertambah.

Tidak ada persyaratan khusus untuk mendeteksi gangguan TI, sehingga tidak bisa menekan risiko error yang akan terjadi. Kami menyarankan agar Dinas Pertanian mempunyai pengendalian mengenai sistem tersebut dan melakukan pemeliharaan secara rutin karena kelangsungan sistem akan terkena dampaknya. Sebenarnya sistem Pa'Tani dapat meningkatkan level jika penilaian risiko sudah dirancang oleh Dinas Pertanian sehingga nantinya akan membantu dalam mendeteksi gangguan.

Dalam sistem tersebut telah memenuhi persyaratan bisnis untuk menjaga kerahasiaan, integritas, dan ketersediaan

informasi serta infrastruktur pemrosesan yang selaras dengan kebutuhan bisnis dan meminimalkan dampak kerentanan keamanan dengan adanya password dan username dalam mengakses sistem tersebut. Tetapi masalah ketersediaan dan kinerja belum bisa ditangani dengan maksimal karena adanya keterbatasan sumber daya manusia. Kami menyarankan agar keamanan untuk sistem tersebut ditambah yaitu adanya CCTV di dalam ruangan agar dapat mengurangi risiko

pencurian hardware. Sistem Pa'Tani dapat meningkat ke level selanjutnya karena adanya pengecekan berulang mengenai hardware dan software sehingga informasi dapat terjamin dengan aman.

Sistem Pa'Tani telah memenuhi persyaratan bisnis dengan menggunakan aplikasi dan solusi teknologi secara efektif dan efisien dan memastikan kepatuhan pengguna terhadap kebijakan dan prosedur. Sistem Pa'Tani mengikuti kebijakan dan prosedur yang dibuat oleh Pemerintah Kota Salatiga belum dilakukan secara maksimal, jika ada peraturan yang mengalami perubahan maka pemangku kepentingan akan diberi tahu sehingga tidak terjadi kesalahan. Kami menyarankan agar Dinas Pertanian melakukan secara maksimal kebijakan dan prosedur yang telah dibuat karena akan berdampak dalam mengatasi eror yang terdapat dalam sistem tersebut. Dalam hal ini, Dinas Pertanian tetap mengoptimalkan terlebih dahulu level ini untuk mendeteksi gangguan serta perubahan yang terdapat dalam sistem.

Sistem Pa'Tani telah mengoptimalkan infrastruktur, sumber daya, kemampuan TI, dan akuntansi untuk aset TI. Sumber daya manusia telah menggunakan pengetahuan yang dimiliki dengan baik dan telah melakukan pelatihan sesuai dengan bidangnya. Kami menyarankan agar dapat meningkatkan pengetahuannya untuk mendukung persyaratan yang ada dan memberikan tugas yang pasti dan tepat untuk setiap 
kemampuan yang dimiliki para karyawan agar tidak terjadi pekerjaan di luar bidangnya. Pa'Tani dapat meningkatkan ke level selanjutnya karena karyawan telah melakukan pelatihan dan menggali pengetahuan yang dimiliki oleh karyawan agar sesuai dengan fenomena yang ada dan update mengenai perkembangan teknologi serta penangan khusus saat terjadi gangguan.

Sistem Pa'Tani menjawab kebutuhan masyarakat dengan memberikan layanan kepada masyarakat luas dan petani di Kota Salatiga dengan memberikan solusi dalam memutus rantai distribusi. Informasi yang terdapat dalam sistem Pa'Tani belum menunjukkan keadaan saat ini karena adanya petani yang tidak melakukan update barang. Kami menyarankan agar dilakukan penyuluhan dan pemeriksaan sistem secara rutin dan berkala, dapat juga dengan memperbaiki tampilan yang ada di sistem untuk mempermudah pengoperasian sistem tersebut. Sistem tersebut

BAI09 1125
dapat meningkat ke level selanjutnya karena $\mathrm{Pa}$ 'Tani harus diperbaiki dan dilakukan pemeliharaan untuk tetap menjadi solusi dalam jual beli yang dilakukan dalam sistem tersebut.

Dinas Pertanian memastikan penggunaan informasi di sistem Pa'Tani telah mendapatkan informasi sesuai kebutuhan. Informasi di Pa'Tani juga digunakan dalam mengambil keputusan mengenai harga yang ditawarkan, kuantitas barang, serta deskripsi produk. Kami menyarankan agar Dinas Pertanian memperbaharui informasi yang digunakan di sistem Pa'Tani agar informasi tersebut relevan dan dalam mengambil keputusan sesuai dengan fenomena yang sedang terjadi dan tidak memberikan kesalahan secara material, maka dari itu Dinas Pertanian perlu mengoptimalkan level ini agar keputusan yang diambil tidak salah dan tepat dengan masalah yang ada.

Kegiatan operasional yang terdapat di Sistem $\mathrm{Pa}$ ' Tani sudah dilakukan secara terjadwalkan. Dinas pertanian belum memiliki pedoman khusus akses lingkungan fisik untuk melindungi data dan informasi saat mengakses ke komputer. Perlindungan data dan informasi hanya sekedar melalui username dan password yang ada. Dinas Pertanian akan mengoptimalkan pengamanan untuk melindungi akses langsung ke komputer. Kami menyarankan agar Dinas Pertanian memiliki pedoman khusus untuk perlindungan lingkungan fisik serta Dinas Pertanian dapat memasang CCTV yang langsung diarahkan ke komputer agar keamanan lebih terjamin.

Sistem Pa' Tani yang ada di Dinas Pertanian sedang mengalami eror sehingga mengganggu jalannya kegiatan operasional yang ada, sistem tersebut belum pulih sepenuhnya. Dinas Pertanian belum bisa memecahkan masalahnya secara internal maka Dinas Pertanian berencana akan memperbaiki sistem tersebut dengan menggandeng pihak ke tiga (ahli IT) agar sistem tersebut dapat digunakan kembali seperti semula untuk kegiatan operasional.

$\begin{array}{llll}\operatorname{DSS} 02 & 0 & 1 & 5\end{array}$
Kami menyarankan agar Dinas Pertanian memaksimalkan kinerja Prakom yang ada, karena mengingat syarat prakom adalah seorang yang paham mengenai IT, dengan memaksimalkan kerja prakom maka dapat menekan biaya untuk keluar pula. Sistem $\mathrm{Pa}^{\prime}$ Tani sudah memenuhi transparansi bisnis serta memiliki kebijakan sesuai dengan persyaratan tata kelola yang ada. Sistem Pa' Tani dibuat berdasarkan peraturan pemerintah kota, selain itu ada juga kebijakan internal Dinas Pertanian terkait dengan tata kelola sistem tersebut. Dinas Pertanian masih ingin $\begin{array}{lllll}\mathrm{DSS} 03 & 1 & 1 & 5 & \text { mengoptimalkan kinerja sistem tersebut agar semakin selaras }\end{array}$ 
dengan peraturan yang berlaku khususnya peraturan terkait IT. Kami menyarankan agar

DSS04 $11 \quad 1 \quad 5$

DSS05 $\quad 1 \quad 2 \quad 5$

$\begin{array}{llll}\text { DSS06 } & 0 & 1 & 5\end{array}$

$\begin{array}{llll}\text { MEA01 } & 1 & 1 & 5\end{array}$

MEA02 115

Dinas Pertanian mempertahankan koordinasi yang baik dengan Dinas Kominfo terkait dengan transparansi anggaran biaya pada sistem tersebut.

Sistem Pa' Tani sudah memiliki pengendalian internal berupa password dan SOP yang sudah diterapkan. Tetapi penerapan dirasa belum optimal karena sumber daya yang ada di Dinas Pertanian memiliki fokus yang terpecah-pecah tidak hanya pada satu bidang saja. Dinas Pertanian akan mempertahankan dan masih memperbaiki lagi terkait dengan permasalahan sumber daya manusia yang ada. Kami menyarankan agar Dinas Pertanian lebih mengoptimalkan sumber daya yang ada agar lebih berfokus pada bidangnya masing-masing.

Sistem $\mathrm{Pa}$ ' Tani sejalan dengan standar kebijakan yang dikeluarkan oleh pemerintah kota dalam menunjang penggunaan sistem dengan hal ini maka sistem tersebut dapat berjalan sejalan dengan peraturan yang ada Strategi, rencana, dan persyaratan di dalam sistem Pa'Tani dipahami dengan baik, didokumentasikan dan disetujui oleh Kepala Dinas Pertanian. Dinas Pertanian belum memiliki pengendalian terkait dengan akses fisik yang ada di Dinas Pertanian, Dinas Pertanian memiliki rencana untuk meningkatkan pengamanan yang ada dengan cara lebih mengamankan akses fisik yang ada. Kami menyarankan agar Dinas Pertanian juga memasang CCTV untuk memantau segala akses fisik yang langsung berhubungan dengan sistem.

Sistem Pa' Tani belum memiliki tata kelola yang baik, hal ini dikarenakan terpecahnya fokus sumber daya manusia yang ada dan kurangnya pengetahuan para petani terkait dengan teknologi. Dinas Pertanian berencana akan memberikan tata kelola yang baik dengan memperbaiki tugas dan kinerja dari Prakom yang ada. Kami menyarankan agar Dinas Pertanian mengajukan penambahan sumber daya ke dinas pusat untuk mengatasi kekurangan sumber daya yang ada, selain itu Dinas Pertanian juga harus melakukan penyuluhan dan pelatihan kembali terhadap para petani yang ada.

Sistem $\mathrm{Pa}$ ' Tani memiliki output laporan yang berisi tentang produk yang dihasilkan oleh kelompok tani, berguna untuk update data kelompok tani yang ada di Dinas Pertanian. Data tersebut juga dapat digunakan dalam hal pengambilan keputusan. Dinas Pertanian masih akan mengoptimalkan hal ini, dikarenakan sistem pa' tani sedang mengalami eror dan masih perlu adanya berbaikan kembali. Kami menyarankan agar Dinas Pertanian segera memperbaiki sistem yang ada dengan berkoordinasi dengan kominfo atau pihak ke tiga (ahli IT)

Proses dan informasi yang ada di sistem pa' tani sudah memenuhi persyaratan pengendalian internal yang ada untuk perusahaan, akan tetapi sumber daya yang ada masih belum memenuhi dikarenakan minimnya sumber daya yang ada. Dinas Pertanian masih ingin mengoptimalkan sumber daya yang ada pada tiap bidangnya, agar konsentrasi tidak terpecah-pecah. Kami menyarankan agar Dinas Pertanian mengoptimalkan kinerja sumber daya dengan cara memberikan tugas yang pasti dan tepat 
untuk setiap kemampuan yang dimiliki para karyawan.

$\begin{array}{llll}\text { MEA03 } & 1 & 1 & 5\end{array}$

Sistem Pa' Tani sesuai dengan kebijakan yang dikeluarkan oleh pemerintah kota dalam menunjang penggunaan sistem dengan hal ini maka sistem tersebut dapat berjalan sejalan dengan peraturan yang ada. Kebijakan yang ada tidak secara rutin diperbarui, Dinas Pertanian masih mempertahakan kebijakan-kebijakan yang ada. Kami menyarankan agar Dinas Pertanian tetap harus memperbarui secara rutin kebijakan dengan disesuaikan dengan fenomena dan kendala yang ada.

\section{SIMPULAN}

Dari hasil pelaksanaan kegiatan pengabdian masyarakat ini, dapat disimpulkan bahwa kegiatan pengabdian masyarakat sebagai wujud dari pelaksanaan Tridharma perguruan tinggi memberikan manfaat dan menambah pengetahuan bagi kami tentang pengelolaan dan penggunaan sistem informasi pada Dinas Pertanian Kota Salatiga. Secara keseluruhan sistem informasi pada Dinas Pertanian Kota Salatiga yaitu Sistem Pa'Tani sudah berjalan lancar dan dikelola dengan baik sesuai tujuan dan kebutuhan yang diinginkan.

Kegiatan pengabdian masyarakat ini dapat terselenggara dengan baik dan berjalan lancar sesuai dengan rencana kegiatan yang telah disusun serta sebagai laporan akhir mata kuliah Praktik-Praktik Audit Sistem Informasi yang telah diberikan oleh dosen pengajar.Kegiatan pengabdian masyarakat ini hendaknya dapat terus dilaksanakan guna menambah wawasan dan pengetahuan bagi mahasiswa serta mendorong mahasiswa untuk bersosialisasi dengan masyarakat dan memberikan kontribusi nyata.

\section{DAFTAR PUSTAKA}

Hakim, A., Saragih, H., Suharto, A., Studi, P., Informatika, T., Tinggi, S., \& Informatika, M. (2014).Jurnal Sistem Informasi ( Journal of Information Systems ). 2 / 10 ( 2014 ), 108-117 DOI : http://dx.doi.org/10.21609/jsi.v10i2.393. 10, 108-117.

Setiawan, A.(2016). YOGYAKARTA DENGAN MODEL COBIT FRAMEWORK. 2016 (semnasIF), 18-26. 


\section{LAMPIRAN}

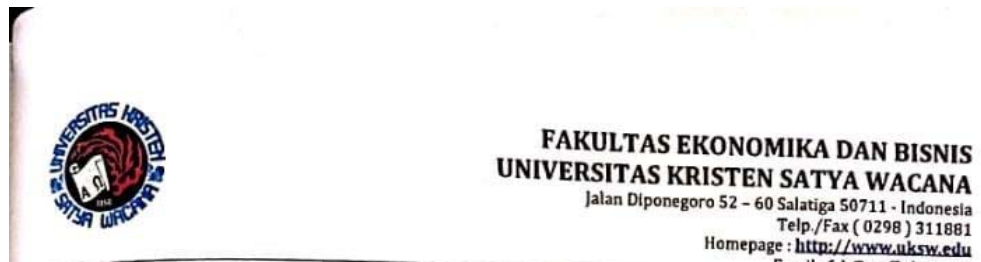

\section{SURAT TUGAS}

No. : 155.4/AKT/X/2019

Pimpinan Program Studi S1 Akuntansi Fakultas Ekonomika Dan Bisnis (FEB) Universitas Kristen Satya Wacana Sałatiga dengan ini memberikan tugas kepada :
Tim Pengabdi : Aprina Nugrahesthy Sulistya Hapsari, SE.,M.Ak
Yosua Febrian Putra Aditya $\quad 232016182$
Debora Herni Kurnianingtyas $\quad 232016179$
Meike Indri Ferosa 232016191

Instansi $\quad$ : Fakultas Ekonomika Dan Bisnis (FEB)

Universitas Kristen Satya Wacana Salatiga

Untuk melaksanakan pengabdian masyarakat, yang dilaksanakan pada:

$\begin{array}{ll}\text { Tanggal } & : 23 \text { September }-15 \text { November } 2019 \\ \text { Tempat } & : \text { Dinas Pertanian Kota Salatiga } \\ & \text { J. Menur No. 27, Kota Salatiga } \\ \text { Judul } & : \text { Analisis Tata Kelola Teknologi dan Sistem Informasi di Dinas } \\ & \text { Pertanian Kota Salatiga }\end{array}$

Semua bantuan yang diberikan kepada yang bersangkutan dalam melaksanakan tugas tersebut, kami ucapkan terima kasih.
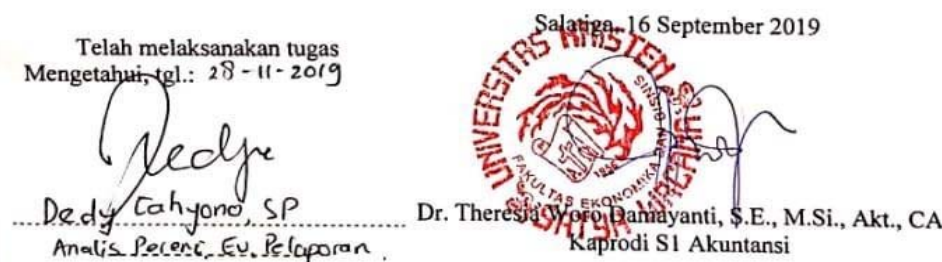
FAKULTAS EKONOMTKA \& BISNIS UNIVERSITAS KRISTEN SATYA WACANA

J1. Diponegoro 52-60, Salatiga 50711 Telp./Fax: (0298)311881

BERITA ACARA KEGIATAN

PENGABDIAN MASYARAKAT

PRODI AKUNTANSI

FAKULTAS EKONOMIKA DAN BISNIS

UNIVERSITAS KRISTEN SATYA WACANA

Semester 1 Tahun 2019/2020

Dalam rangka pengabdian masyarakat telah dilaksanakan kegiatan Analisis Tata Kelola Teknologi dan Sistem Informasi pada:

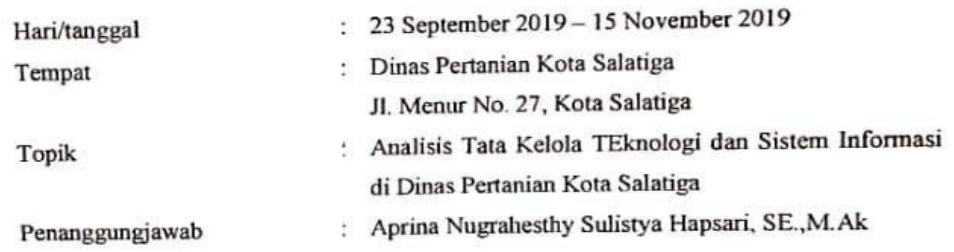

Demikian Berita Acara Kegiatan Pengabdian Masyarakat ini dibuat dengan sesungguhnya.

Salatiga, 28 November 2019

Pimpinan Organisasi

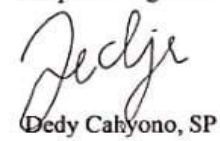

$m \cdot n \cdot$.
Aprina Nugrahesthy Sulistya Hapsari, SE., M.Ak 